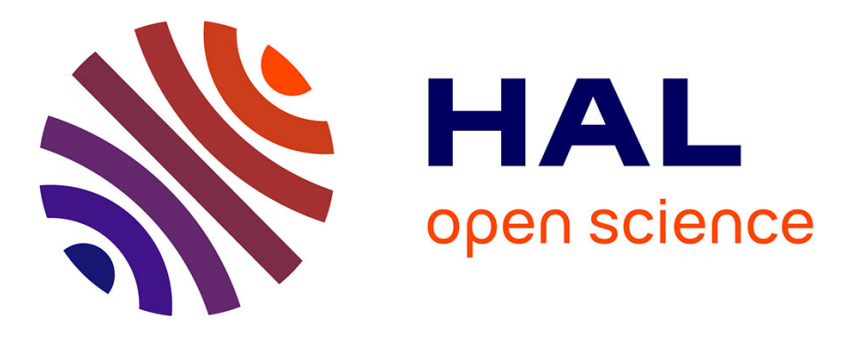

\title{
Mechanical and thermo-physical properties of plasma-sprayed thermal barrier coatings: a literature survey
}

Pierre Planques, Vanessa Vidal, Philippe Lours, Vincent Proton, Fabrice Crabos, Julitte Huez, Bernard Viguier

\section{To cite this version:}

Pierre Planques, Vanessa Vidal, Philippe Lours, Vincent Proton, Fabrice Crabos, et al.. Mechanical and thermo-physical properties of plasma-sprayed thermal barrier coatings: a literature survey. Oxidation of Metals, 2017, vol. 88 ( $\mathrm{n}^{\circ}$ 1-2), p.133-143. 10.1007/s11085-016-9693-1 . hal-01579759

\section{HAL Id: hal-01579759 \\ https://hal.science/hal-01579759}

Submitted on 31 Aug 2017

HAL is a multi-disciplinary open access archive for the deposit and dissemination of scientific research documents, whether they are published or not. The documents may come from teaching and research institutions in France or abroad, or from public or private research centers.
L'archive ouverte pluridisciplinaire HAL, est destinée au dépôt et à la diffusion de documents scientifiques de niveau recherche, publiés ou non, émanant des établissements d'enseignement et de recherche français ou étrangers, des laboratoires publics ou privés. 


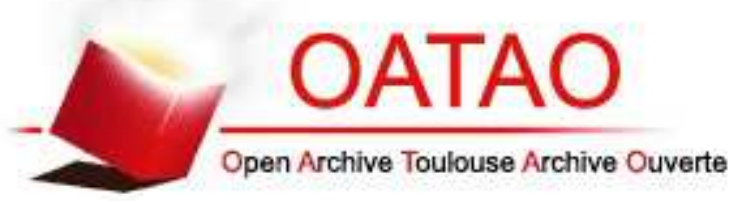

\section{Open Archive TOULOUSE Archive Ouverte (OATAO)}

OATAO is an open access repository that collects the work of Toulouse researchers and makes it freely available over the web where possible.

This is an author-deposited version published in: http://oatao.univ-toulouse.fr/ Eprints ID : 18119

To link to this article: DOI: $10.1007 / \mathrm{s} 11085-016-9693-1$

URL: http://dx.doi.org/10.1007/s11085-016-9693-1

To cite this version: Planques, Pierre and Vidal, Vanessa and Lours, Philippe and Proton, Vincent and Crabos, Fabrice and Huez, Julitte and Viguier, Bernard Mechanical and thermo-physical properties of plasma-sprayed thermal barrier coatings: a literature survey.

(2017) Oxidation of Metals, vol. 88 ( $\left.n^{\circ} 1-2\right)$. pp. 133-143. ISSN

0030-770X

Any correspondence concerning this service should be sent to the repository administrator: staff-oatao@ listes-diff.inp-toulouse.fr 


\title{
Mechanical and Thermo-physical Properties of Plasma- Sprayed Thermal Barrier Coatings: A Literature Survey
}

\author{
Pierre Planques ${ }^{1,2,3}$. Vanessa Vidal ${ }^{2}$. \\ Philippe Lours ${ }^{2}$ - Vincent Proton $^{3}$ - Fabrice Crabos ${ }^{3}$. \\ Julitte Huez $^{1} \cdot$ Bernard Viguier $^{1}$
}

\begin{abstract}
Atmospheric plasma-sprayed thermal barrier coatings (APS TBCs) have been studied from an extensive review of the dedicated literature. A large number of data have been collected and compared, versus deposition parameters and/or measurement methods, and a comparison was made between two different microstructures: standard APS coatings and segmented coatings. Discussion is focused on the large scattering of results reported in the literature even for a given fabrication procedure. This scattering strongly depends on the methods of measurement as expected, but also-for a given method-on the specific conditions implemented for the considered experimental investigation. Despite the important scattering, general trends for the correlation of properties to microstructure and process parameters can be derived. The failure modes of TBC systems were approached through the evolution of cracking and spalling at various life fractions.
\end{abstract}

Keywords Air plasma sprayed (APS) - Thermal barrier coatings (TBC) · Mechanical properties · Cracking

\section{Introduction}

Atmospheric plasma-sprayed thermal barrier coatings (APS TBCs) are widely used in hot sections of gas turbine engines as thermal insulation systems. The current state of the art for manufacturing APS TBCs consists in a bilayer system composed

Pierre Planques

pierre.planques@ensiacet.fr

1 CIRIMAT, Université de Toulouse, CNRS, INPT, UPS, 4 allée Emile Monso, BP 44362, 31030 Toulouse Cedex 04, France

2 CNRS, Mines Albi, INSA, UPS, ISAE; ICA (Institut Clément Ader), Université de Toulouse, Campus Jarlard, 81013 Albi, France

3 Safran Helicopter Engines, Avenue Joseph Szydlowski, 64511 Bordes, France 
of a $150-\mu \mathrm{m}$-thick MCrAlY bond coat and a 250 - to $500-\mu \mathrm{m}$-thick ceramic top coat of $\mathrm{ZrO}_{2}$ stabilized with 7-8 wt $\% \mathrm{Y}_{2} \mathrm{O}_{3}$, labeled YSZ. However, following the cumulative cooling related to successive thermo-mechanical cycles imposed to the engine, the thermal expansion misfit between the metallic substrate and the ceramic layer results in thermo-mechanical fatigue leading to a progressive and irreversible damage of the deposit. The failure of plasma-sprayed TBCs upon thermal cycling is usually induced by the spallation of ceramic coating. Consequently, understanding such spalling phenomena and predicting the life of the thermal barriers are major issues for engine makers willing to build and properly implement a relevant model of life to be used for design purpose. This, previously, requires a precise knowledge of the experimental background in the field, and the present work proposes a comprehensive synthesis based on an extensive review of the dedicated literature. A large number of data have been collected and compared, using deposition parameters and/or measurement methods and/or characteristics of cycling as objective criteria of selection. Discussion is focused on the large scattering of results reported in the literature even for a given and fixed fabrication procedure. This scattering strongly depends on the methods of measurement as expected, but alsofor a given method-on the specific conditions implemented for the considered experimental investigation.

\section{Process and Coatings Microstructure}

Plasma spraying is intended to manufacture thermal barriers with a thickness ranging from $250 \mu \mathrm{m}$ to $1 \mathrm{~mm}$ mainly on static parts as combustion chambers or outer air seals (segments or rings) in aircraft engines and on blades and vanes in land-based engines. It is well known that the thermo-physical and mechanical properties of plasma-sprayed thermal barrier coatings strongly depend on the microstructure, and therefore on process parameters.

First, data related to standard lamellar, porous, and micro-cracked microstructure, classically obtained by APS deposition, have been collected. This type of APS coating has been extensively investigated, and a large number of various studies are available [1-11]. As shown on Fig. 1a, b [3], standard APS coatings typically show lamellar microstructure, due to interlamellar porosity between the superposition of splats. The resulting total porosity, composed of interlamellar and globular porosity, reaches quite high values, generally greater than $10 \%$. As the pores and cracks play a major role in the resulting thermo-physical properties such as thermal conductivity, this high porosity results in a good insulation capacity. APS porous and micro-cracked coatings have a low thermal conductivity, between 0.6 and $1 \mathrm{~W} /$ $\mathrm{mK}$, compared to dense zirconia, $2.25 \mathrm{~W} / \mathrm{mK}$. This satisfactory insulation is straightforwardly related to the preferred orientation of pores and cracks perpendicular to the preferential direction of heat flow. Note however that this microstructure has a poor mechanical compliance, and therefore a limited thermal fatigue resistance.

On the other hand, our research is focused on dense, vertically segmented or cracked (DVC) microstructure, characteristic of hot spraying and thick coating 

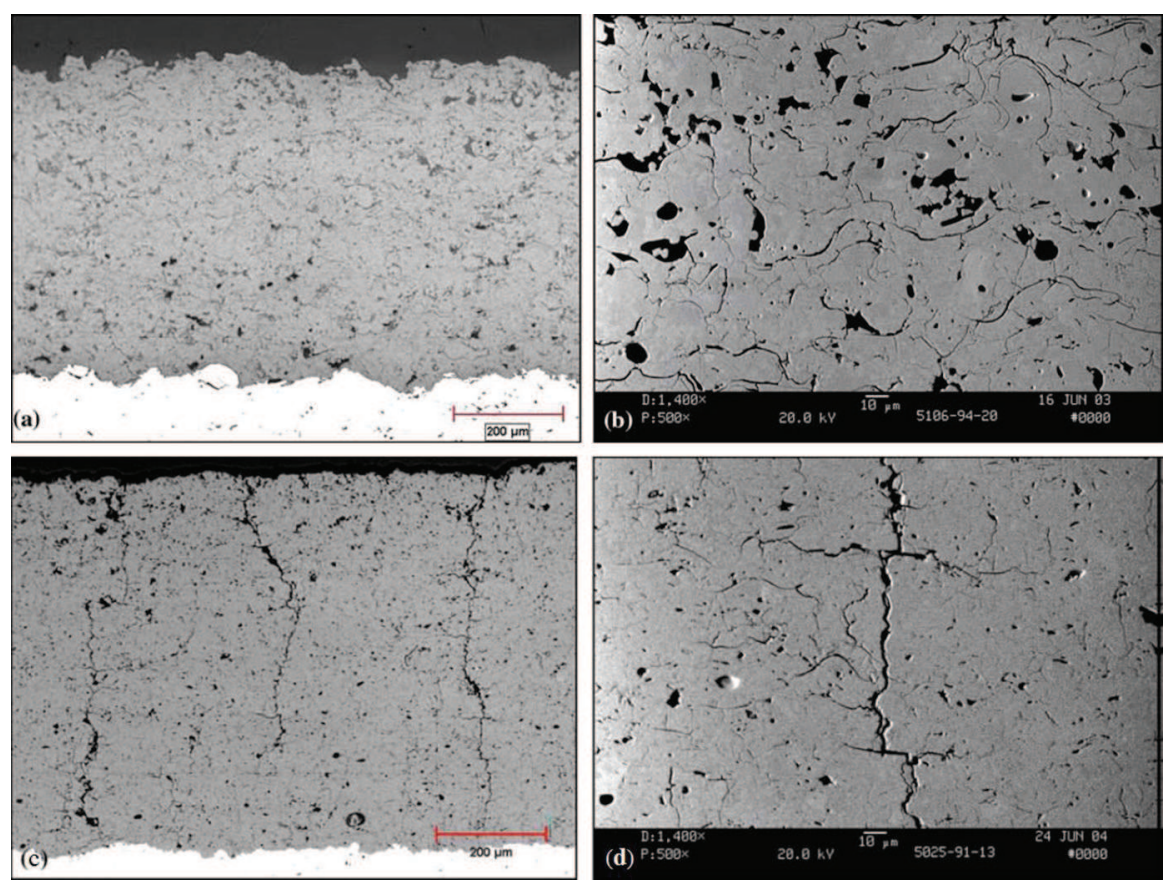

Fig. 1 a, b Cross section of APS low-density TBC, containing approximately $15 \%$ porosity. Two different magnifications are shown. $\mathbf{c}, \mathbf{d}$ Cross section of APS DVC TBC, containing approximately 1.6-2.4 cracks per linear millimeter. Two different magnifications are shown Extracted from [3]

(1 mm) [3, 12-21]. The most important difference with the standard APS coating is the global columnar structure (Fig. 1c, d) [3]. Indeed, vertical cracks run through the coating, parallel to the direction of heat flow, forming segments on cross sections, and columns in 3D. Within the coating, between those macro-cracks, and as a consequence of the specific implemented process parameters, the porosity is smaller than in APS coatings, resulting in a higher thermal conductivity, from 1.2 to $1.6 \mathrm{~W} /$ $\mathrm{mK}$, close to values of an electron beam physical vapor deposition (EBPVD) coating. Unlike standard APS deposit, segmented coatings show good mechanical compliance and provide improved tolerance of the ceramic layer to the strain [3].

\section{Properties of APS TBC}

In industry, Young's modulus is one of the standard, most commonly used parameter entering the global description of the mechanical behavior of TBC in the elasticity domain. It determines the response of the coating to a tensile or compressive loading and is subject to special attention. Recent developments [22-25] have shown that ceramic coatings exhibit an anisotropy of elasticity between tension and compression, and hysteresis phenomena in the stress-strain curves relative to their mechanical responses. Cracks opening/closing as well as 
sliding of splats with respect to each other results in a non-linear response and allows a high tolerance for deformation, as stress is easily accommodated. Resulting differences can be observed depending on the type (tension, compression), the magnitude, and the level of solicitation (macro/micro) of the applied load.

The large scattering can be attributed to variations in methods of measurement and - for a given method - to the considered experimental investigation such as the residual stress, the anisotropy of the porosity (normal/parallel to the spray direction), and the initial size of powders.

From a literature survey, general trends regarding the correlation between the engineering properties and both the microstructure and the process parameters can be highlighted.

For lamellar structure, data show a general tendency for the Young's modulus to decrease with the increase of porosity, as shown in Fig. 2 [13-18, 26-36]. Such a dependence is much less clear for DVC coatings since the inter-crack porosity is nearly constant. However, it is established that the Young's modulus decreases with increasing density of segmentations (Fig. 3a) [10, 15, 19, 21]. For an as-sprayed coating, literature reports typical values in the range of 5-60 GPa for a global measurement technique, giving apparent Young's modulus, higher in compression than in tension. The elongation is generally $0.2-0.4 \%$ [26, 34-36]. These values are considerably lower than those, typically 200-220 GPa, for dense sintered zirconia. A method based on local measurement, such as the indentation technique, gives Young's modulus values close to that of the dense material, typically from 70 to $150 \mathrm{GPa}$. Indeed, in such a case, the area subject to deformation is likely to contain much less detrimental defects, assuming to be responsible for the low values obtained with more global techniques.

In the temperature range from room temperature to $1200{ }^{\circ} \mathrm{C}$, the modulus values tend to decrease, of about $20-50 \%$ [27, 28, 37-40].

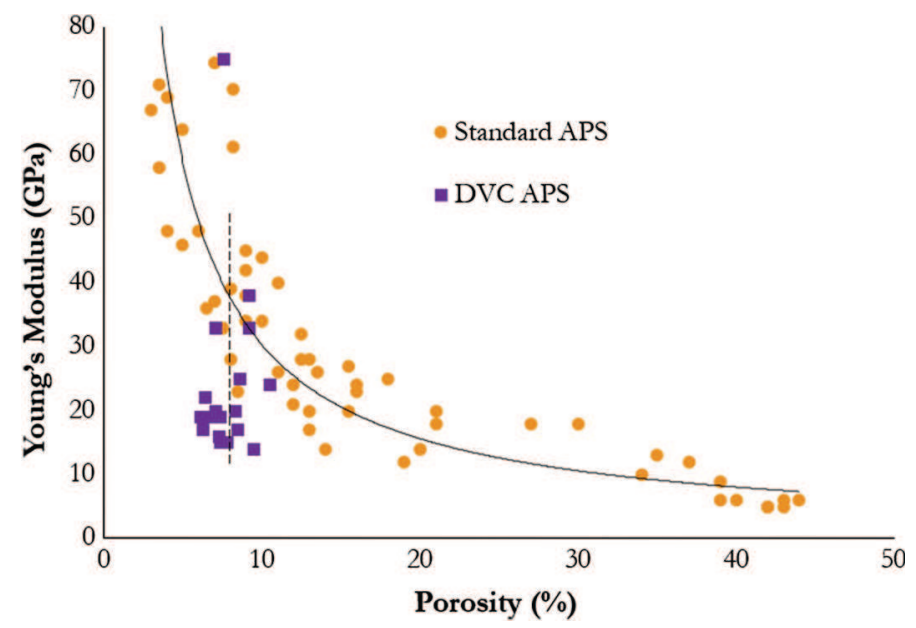

Fig. 2 Young's modulus as a function of porosity. Solid line denotes master curve for standard APS coatings. Dotted line denotes master curve for DVC APS coatings From [13-18, 26-36] 

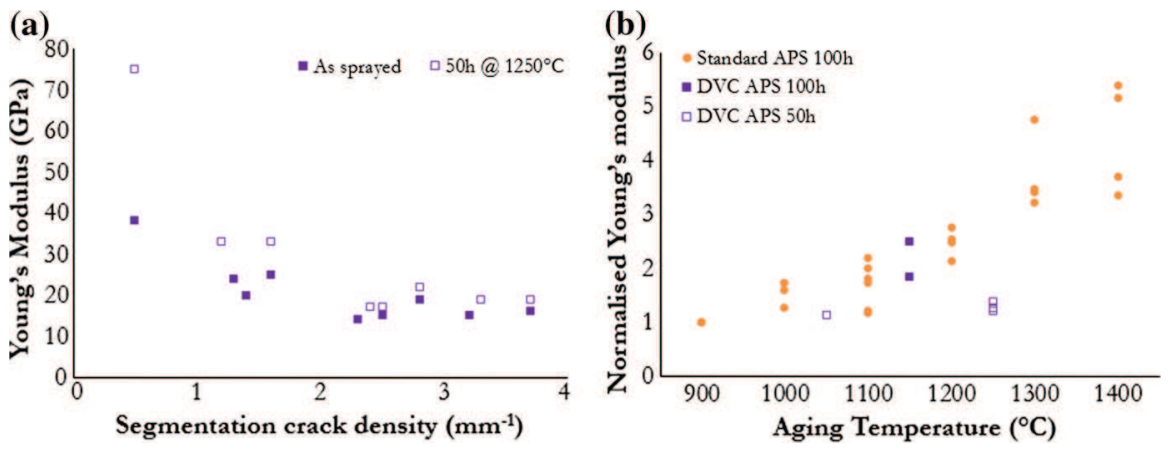

Fig. 3 a Young's modulus as a function of segmentation crack density, data from [10, 15, 19, 21]. b Normalized Young's modulus measured at room temperature as function of aging temperature, data from $[35,41,42]$

In addition, in gas turbines, and for long exposure times to high temperatures, changes in stiffness during operation can be really significant and critical. A continuous increase in stiffness was observed over $1000{ }^{\circ} \mathrm{C}$ by many researchers $[35,41,42]$. The stiffening underlying mechanisms are related to sintering and the associated microstructural changes upon temperature exposure. For lamellar structure exposed at high temperature (Fig. 3b), sintering occurs and leads to an increase by a factor 5 for modulus values. The sintering speed and rate are functions of the temperature and the initial porosity into the coating.

DVC zirconia has a different behavior: sintering effect is limited (Fig. 3a), due to plasma spraying in hot conditions conferring a nearly non-lamellar microstructure and stability of macro-cracks versus temperature. However, Thompson et al. $[35,36]$ showed that the behavior of thermal barriers tested in free-standing conditions and those tested as a complete system is different: the presence of the substrate significantly reduces the rate of stiffening of ceramics. It is concluded that, because of the large thermal expansion coefficient of the metal substrate and bond coat, micro-cracks are kept open at elevated temperatures. Thus, it becomes clear that the sintering kinetics is a function not only of the holding temperature and the microstructure of the coating, but also of the thermal stress.

Similarly to Young's modulus, other important mechanical properties such as for instance strength or toughness are lower for coatings than for the dense monolithic material as summarized in Table 1. The evaluation of these properties is subject to the same limitations encountered previously, accounting for the dispersion of values. Indeed, the distinction between local and apparent measurement as well as the tension/compression anisotropy must still be considered. Overall, DVC coatings have higher intrinsic mechanical properties than standard coatings. This is probably due to the "hot" projection used for depositing DVC thermal barriers leading to a lower porosity, and a better adhesion between splats, resulting in a microstructure closer to the dense zirconia. Conversely, the apparent mechanical resistance is weaker. 
Table 1 Main thermo-physical and mechanical properties of $\mathrm{ZrO}_{2}-8 \% \quad \mathrm{Y}_{2} \mathrm{O}_{3}$

\begin{tabular}{|c|c|c|c|}
\hline Property & $\begin{array}{l}\text { Plasma thermal barrier } \\
\text { coating }\end{array}$ & $\begin{array}{l}\text { Vertically cracked } \\
\text { plasma thermal barrier } \\
\text { coating }\end{array}$ & Dense zirconia \\
\hline Density $\left(\mathrm{g} / \mathrm{cm}^{3}\right)$ & $5.1-5.4$ & $5.5-5.7$ & 6.05 \\
\hline $\begin{array}{l}\text { Coefficient of } \\
\text { thermal expansion } \\
\left(10^{-6} \mathrm{~K}^{-1}\right) \\
\text { (domain } \\
20-1000{ }^{\circ} \mathrm{C} \text { ) }\end{array}$ & $9-10$ & $9-10$ & 10.3 \\
\hline $\begin{array}{l}\text { Thermal } \\
\text { conductivity (W/ } \\
\text { mK) } \\
(\text { domain } \\
\left.20-1000{ }^{\circ} \mathrm{C}\right)\end{array}$ & $0.6-1$ & $1.3-1.6$ & $2.2-2.8$ \\
\hline $\begin{array}{l}\text { Young's modulus } \\
\text { (GPa) }\end{array}$ & $\begin{array}{l}10 \text { in bending test } \\
13 \text { in tension } \\
25 \text { in compression } \\
37 \text { by dynamic } \\
\text { measurement } \\
60-150 \text { by indentation } \\
\text { test }\end{array}$ & $\begin{array}{l}2-4 \text { in tension } \\
4-8 \text { in compression } \\
15-25 \text { by dynamic } \\
\text { measurement } \\
>80 \text { by indentation } \\
\text { test }\end{array}$ & $\begin{array}{l}205 \text { by dynamic } \\
\text { measurement (Impulse- } \\
\text { Excitation-Technique) }\end{array}$ \\
\hline Strength (MPa) & $\begin{array}{l}13 \text { in tension } \\
33 \text { in bending test } \\
300 \text { in compression }\end{array}$ & $\begin{array}{l}7 \text { in tension } \\
15 \text { in bending test } \\
- \text { compression }\end{array}$ & $\begin{array}{l}350 \text { in tension } \\
1000 \text { in bending test } \\
2000 \text { in compression }\end{array}$ \\
\hline Poisson coefficient & $\begin{array}{l}0.04-0.18 \text { in } \\
\text { compression } \\
0.3 \text { attached to substrate }\end{array}$ & $\begin{array}{l}0.034 \text { in compression } \\
0.3 \text { attached to } \\
\text { substrate }\end{array}$ & $0.23-0.33$ \\
\hline $\begin{array}{l}\text { Fracture toughness } \\
(\mathrm{MPa} \sqrt{\mathrm{m}})\end{array}$ & $\begin{array}{l}\text { Mode I: } \\
1-1.2 \text { by SEVNB } \\
1.8-2.2 \text { by indentation } \\
\text { test and DCB } \\
\text { Mode II: } \\
0.7 \text { in SEVNB }{ }^{\mathrm{a}}\end{array}$ & $\begin{array}{l}\text { Mode I: } \\
3-4 \text { in DCB } 4-5 \text { by } \\
\text { indentation test }\end{array}$ & $\begin{array}{l}\text { Mode I: } \\
9.5\end{array}$ \\
\hline Hardness (GPa) & $3-7$ & 9 & $>10(>1350 \mathrm{HV})$ \\
\hline $\begin{array}{l}\text { Residual stresses } \\
\text { (MPa) }\end{array}$ & $45-65$ & $30-55$ & - \\
\hline
\end{tabular}

SEVNB single-edge V-notched beam, $D C B$ double cantilever

\section{Failure Modes and Lifetime}

The failure modes of a thermal barrier coating systems are complex, usually involving various mechanisms, and strongly depend on service conditions. However, for standard APS coatings, ruin of the system occurs mainly by spallation 
of the ceramic layer during cooling. In this section, only standard APS coatings are concerned, because of the lack of data concerning cracking in DVC TBCs.

To address TBC failure, it is of utmost importance to determine a criterion able to define as precisely and objectively as possible the end of life of the system. However, depending on the authors, the criterion defining the end of life of a sample can greatly vary: a given cumulative crack length, a percentage of spalled area ranging from 10 to $100 \%$, or a subjective assessment defined as "clear deterioration". The definition of the ruin of the system is particularly critical when data from different publications have to be compared. In order to rationalize our procedure, a failure criterion related to a surface fraction of spall of $100 \%$ has been considered and only data from papers using this approach or data derived in such a way are analyzed. This criterion is not at variance with industrial practice, because it is not valid for an actual component, where the curvature of the surface and inhomogeneous temperature distributions may plan a significant role. Nevertheless, this procedure allows to highlight and understand the mechanisms involved in the TBC spallation in laboratory conditions on simple shape samples.

Clearly, some parameters take on great effect on time to failure. Namely, they are the dwell time (cycling frequency) [43-50], the temperature of the bond coat $[16,18,43-56]$, the minimum temperature reached during cooling time [46, 49, 50, 53, 57], and the thickness of the thermal grown oxide [38, 46, 50, 52, 54-56, 58, 59].The quantity, morphology, and distribution of spallation cracks, lying parallel to the bond coat/YSZ interface, are parameters often analyzed in the literature. There are, for example, many data on the evolution of the maximum and average lengths and the number of cracks as a function of the aging of the TBC system $[46,49,50,53,59,60]$. It has already been shown that rapid cycling decreases the life of a TBC system, but the objective here is to compare the number and propagation velocity of delamination cracks for similar percentages of life. Generally speaking, cyclic exposure conditions produce longer cracks than isothermal exposure. The maximum crack lengths relative to the fraction of life of various TBC systems are shown in Fig. 4, extracted from Ahmadian et al. [49] and modified by additional data. Note that data roughly fit a master curve giving a general trend for crack length evolution whatever the TBC systems (coating thickness, type of bond coat). The same observation can be done for the average length of delamination cracks, not presented here. This is surprising as, depending on the reported research, the cycling temperature ranges vary from 1050 to $1149{ }^{\circ} \mathrm{C}$, the cycling dwell time from 0.5 to $100 \mathrm{~h}$ varies even with values from isothermal hold, and the cumulative time at high temperature at the end of life varies by a factor 50. The maximum crack length steadily increases up to about $100 \mu \mathrm{m}$ during the early life $(20 \%)$ of the barriers. Following this initial degradation, crack lengths stabilize indicating a huge decrease in crack growth rate until half-life (50\%) from which a roughly exponential increase of crack length, corresponding to some coalescence, controls the overall damage of the TBC, leading to final failure. Other studies have reported the same trend of crack growth as function of the fraction of life [46, 57].

In Fig. 5, the crack density as function of the fraction of life is plotted in addition to the maximum crack length curve from Fig. 4. TBC systems with NiCoCrAlY/ 


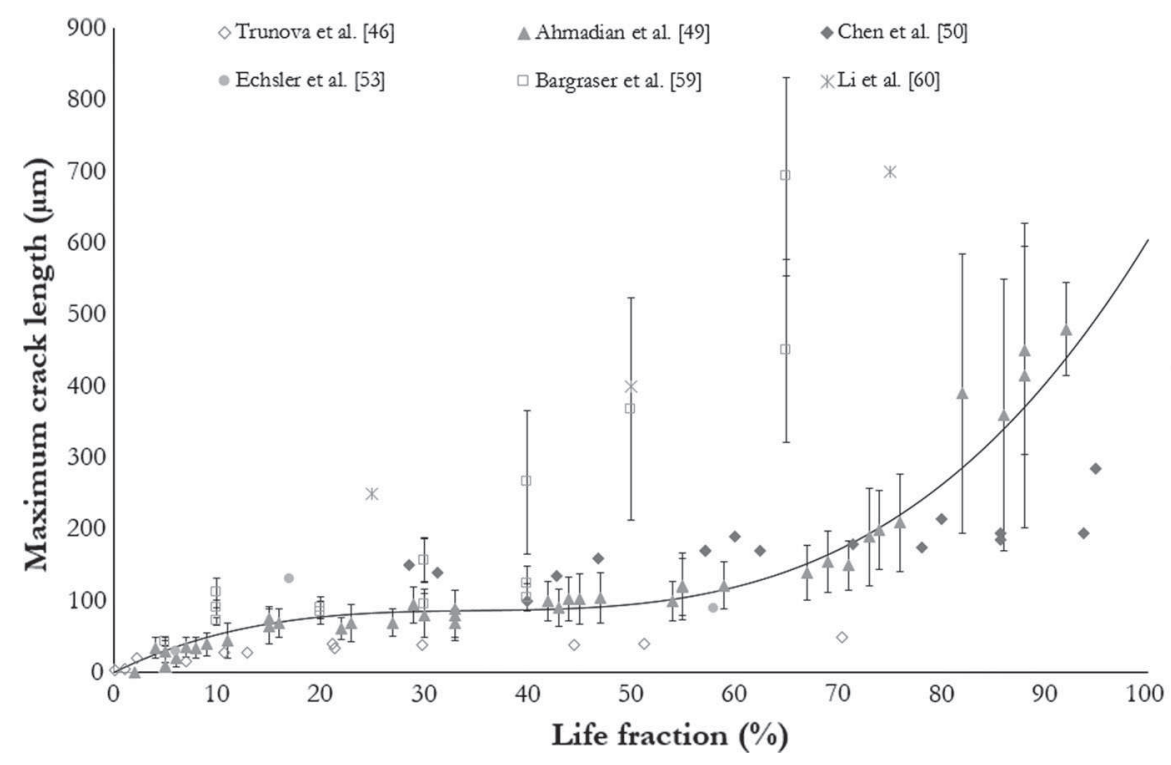

Fig. 4 Crack length at various life fractions for different TBC systems with classical lamellar microstructures Data from $[46,49,50,53,59,60]$

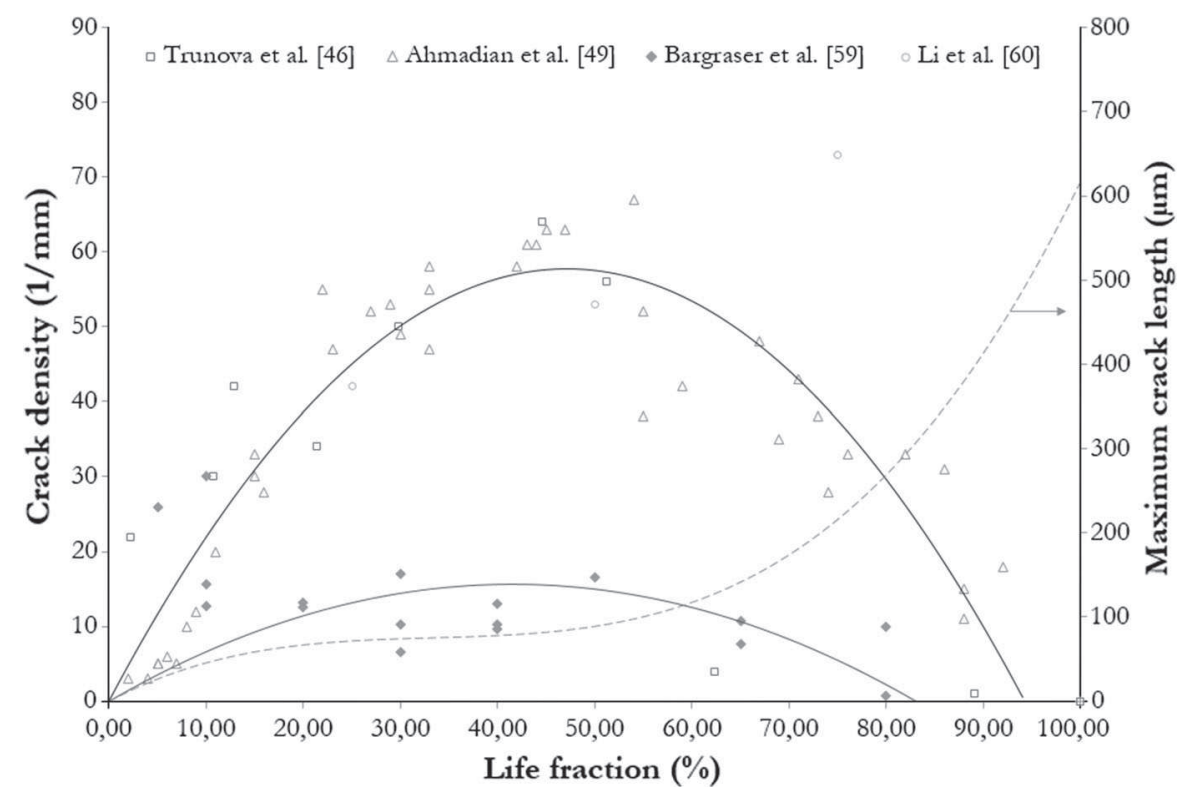

Fig. 5 Number of cracks versus lifetime of TBC. Opened symbols correspond to NiCrAlY/NiCoCrAlY bond coat systems, filled symbols to CoNiCrAlY bond coat systems. Dotted line denotes maximum crack length at various life fractions Data from $[46,49,59,60]$ 
NiCrAlY bond coat show higher values of crack density than TBC system with CoNiCrAlY bond coat. In spite of a rather high dispersion, plots for both systems exhibit however the same quasi-bell shape, indicating a regular increase of crack density up to a life fraction of about $40-50 \%$, followed by almost a symmetrical decrease beyond this threshold. It is interesting to note that the decrease in the crack density (from 60 cracks per mm for a non-CoNiCrAlY bond coat system at half-life) is concomitant to the sudden increase in the maximum crack length reported in the same graph (from $100 \mu \mathrm{m}$ ). Consistently, the enhancement of crack length, due to crack coalescence as discussed above, must in turn result in a correlated decrease of the crack density. Comparable results were given by Beck et al. [57], reporting a half-life threshold of 60 cracks per mm and a length of $40 \mu \mathrm{m}$, slightly lower.

\section{Conclusions}

Two microstructures of $\mathrm{ZrO}_{2}-8 \% \mathrm{Y}_{2} \mathrm{O}_{3}$ coatings obtained by APS were considered: the standard porous lamellar microstructure and the dense vertically segmented microstructure, both with MCrAlY bond coats. A thorough synthesis of their thermo-physical and mechanical properties has been made, comparing a large amount of data. Despite a wide scattering in the results, and considering the anisotropy of behavior due to the microstructure, general trends have been observed. Due to process parameters, the intrinsic properties of DVC coatings are closer to the dense zirconia than the standard coatings, but the global behavior is weaker. The review of standard APS TBC lifetime has shown that cracking, resulting in the spallation of the ceramic coating, follows similar evolution, regardless of the considered TBC systems. However, no similar data are available for segmented coatings in order to establish a comparison of cracking. Further experiments are being carried out to confirm and complete these results.

\section{References}

1. Y. Kuroda, K. Fukaura, H. Sunada and H. Izumi, Journal of the Japan Society of Powder and Powder Metallurgy 38, 787 (1991).

2. L. Bianchi, A. Leger, M. Vardelle, A. Vardelle and P Sfa Fauchais, Thin Solid Films 305, 35 (1997).

3. A. Feuerstein, J. Knapp, T. Taylor, A. Ashary, A. Bolcavage and N. Hitchman, Journal of Thermal Spray Technology 17, 199 (2008).

4. G. Dwivedi, On the Anelastic Behavior of Plasma Sprayed Ceramic Coatings: Observations, Characterizations and Applications, (Stony Brook University, Stony Brook, 2011).

5. N. Curry, Design of Thermal Barrier Coatings, (University West, Trollhättan, 2014).

6. O. Lavigne, M. Poulain, Y. Renollet, C. Rio, P. Moretto, P. Brännvall, J. Wigren, Microstructural characterisation of plasma sprayed thermal barrier coatings by quantitative image analysis, Quantitative Microscopy of High Temperature Materials Conference, November 22-24 1999, Sheffield.

7. A. Allen, J. Ilavsky, G. Long, J. Wallace, C. Berndt and H. Herman, Acta Materialia 49, 1661 (2001).

8. Z. Wang, A. Kulkarni, S. Deshpande, T. Nakamura and H. Herman, Acta Materialia 51, 5319 (2003).

9. P. Scardi, M. Leoni and L. Bertamini, Surface and Coatings Technology 76-77, 106 (1995).

10. D. Schwingel, R. Taylor, T. Haubold, J. Wigren and C. Gualco, Surface and Coatings Technology 108-109, 99 (1998). 
11. M. Friis, C. Persson and J. Wigren, Surface and Coatings Technology 141, 115 (2001).

12. T. Taylor and I. Ind, US Patent 5,073,433 (17 December 1989).

13. H. Guo, Y. Wang, L. Wang and S. Gong, Journal of Thermal Spray Technology 18, 665 (2009).

14. H. Guo, R. Vaßen and D. Stöver, Surface and Coatings Technology 186, 353 (2004).

15. H. Guo, S. Kuroda and H. Murakami, Journal of the American Ceramic Society 89, 1432 (2006).

16. M. Karger, R. Vaßen and D. Stöver, Surface and Coatings Technology 206, 2011 (16).

17. H. Guo, H. Murakami and S. Kuroda, Journal of the American Ceramic Society 89, 3797 (2006).

18. H. Guo, R. Vaßen and D. Stöver, Surface and Coatings Technology 192, 48 (2005).

19. S. Tsipas and I. Golosnoy, Journal of the European Ceramic Society 31, 2923 (2011).

20. R. Vaßen, A. Stuke and D. Stöver, Journal of Thermal Spray Technology 18, 181 (2009)

21. D. Schwingel, R. Taylor, T. Haubold, J. Wigren, C. Gualco, F. Ladru, E. Lugscheider and V. Gourlaouen, in "Thermophysical and mechanical properties of PYZ thick thermal barrier coatings," Thermal Spray: Meeting the Challenges of the 21st Century, ed. C. Coddet, (ASM International, Nice, 1998),p. 623

22. Y. Liu, T. Nakamura, V. Srinivasan, A. Vaidya, A. Gouldstone and S. Sampath, Acta Materialia 55, 4667 (2007).

23. Y. Liu, T. Nakamura, G. Dwivedi, A. Valarezo and S. Sampath, Journal of the American Ceramic Society 91, 4036 (2008).

24. S. Choi, D. Zhu and R. Miller, Mechanical properties of plasma-sprayed ZrO2-7.5\%Y2O3 Thermal Barrier Coatings, NASA/TM-2004-213216, 2004.

25. S. Choi, D. Zhu and R. Miller, Effects of sintering on mechanical and physical properties of plasmaspayed Thermal Barrier Coatings, NASA/TM-2004-212625, 2004.

26. S. Guo and Y. Kagawa, Scripta Materialia 50, 1401 (2004).

27. T. Cruse, B. Johnsen and A. Nagy, Journal of Thermal Spray Technology 6, 57 (1997).

28. K. Ma, H. Xie, J. Zhu and H. Wang, Surface and Coatings Technology 253, 58 (2014)

29. J. Wallace and J. Ilavsky, Journal of Thermal Spray Technology 7, 521 (1998).

30. J. Singh, M. Sutaria and M. Ferber, Ceramic Engineering and Science Proceedings 18, 191 (1997).

31. A. Pajares, L. Wei, B. Lawn, N. Padture and C. Berndt, Mater. Sci. Eng. A 208, 158 (1996).

32. F. Tang and J. Schoenung, Scripta Materialia 54, 1587 (2006).

33. D. Schwingel, R. Taylor, T. Haubold, J. Wigren and C. Gualco, Surface and Coatings Technology 108, 99 (1998)

34. F. Tang and J. Schoenung, Scripta Materialia 54, 1587 (2006).

35. J. Thompson, W. Ji, T. Klocker and T. Clyne, Superalloys, ed. T. M. Pollock et al. (eds) Seven Springs, USA TMS (The Minerals, Metals \& Materials Society), p.685 (2000).

36. J. A. Thompson and T. W. Clyne, Acta Materialia 49, 1565 (2001).

37. D. W. Seo and E. Na, Key Engineering Materials 270-273, 58 (2004).

38. S. Wei, W. Fu-chi, F. Qun-bo and M. Zhuang, Surface and Coatings Technology 217, 39 (2013).

39. J. DeMasi, K. Sheffler and M. Oritz, Thermal barrier coating life prediction developement, Phase I, Final Report, NASA Contractor Report, NASA/CR-1989-182230, 1989.

40. M. Beghini, L. Bertini, F. Frendo and E. Giorni, "Determination of thermal sprayed coatings elastic modulus using four point bending test," in Surface Treatment III: Computer Methods \& Experimental Measurements, Hrsg. ed. M. H. Aliabadi, C. A. Brebbia, 1997.

41. H. Eaton and R. Novak, Surface and Coatings Technology 32, 227 (1987).

42. D. Basu, C. Funke and R. Steinbrech, Journal of Materials Research 14, 4643 (1999).

43. D. Stöver and C. Funke, Journal of Materials Processing Technology 92, 195 (1999).

44. S. K. S. Faulhaber, M. Chambers, D. Clarke, C. Levi, J. Hutchinson and A. Evans, Materials Science and Engineering: A 490, 26 (2008).

45. C. Mercer, S. Faulhaber, A. Evans and R. Darolia, Acta Materialia 53, 1029 (2005).

46. O. Trunova, T. Beck, R. Herzog, R. Steinbrech and L. Singheiser, Surface and Coatings Technology 202, 5027 (2008).

47. E. P. Busso, L. Wright, H. E. Evans, L. N. McCartney, S. R. J. Saunders, S. Osgerby and J. Nunn, Acta Materialia 55, 1491 (2007).

48. W. Nowak, D. Naumenko, G. Mor, F. Mor, D. Mack, R. Vaßen, L. Singheiser and W. Quadakkers, Surface and Coatings Technology 260, 82 (2014).

49. S. Ahmadian and E. Jordan, Surface and Coatings Technology 244, 109 (2014).

50. W. Chen, X. Wu and D. Dudzinski, Journal of Thermal Spray Technology 2, 1294 (2012).

51. M. A. Helminiak, N. Yanar, F. Pettit, T. Taylor and G. Meier, Surface and Coatings Technology 204, 793 (2009). 
52. R. Eriksson, S. Sjostrom, H. Brodin, S. Johanson, L. Ostergren and X. Li, Surface and Coatings Technology 236, 230 (2013).

53. H. Echsler, V. Shemet, M. Schütze, L. Singheiser and W. J. Quaddakers, Journal of Materials science 41, 1047 (2006).

54. K. Schlichting, N. Padture, E. Jordan and M. Gell, Materials Science and Engineering: A 342, 120 (2003).

55. R. Vaßen, S. Giesen and D. Stöver, Journal of Thermal Spray Technology 18, 835 (2009).

56. Z. Lu, M. Kim, S. Miyoung, Y. Balakrishnan, J. Lee and U. Paik, Materials 6, 3387 (2013).

57. T. Beck, O. Trunova, R. Herzog and L. Singheiser, Journal of Power and Energy Engineering 7, 647 (2013).

58. Y. Y. Zhang, H. Deng, H. Shi, H. Yu and B. Zong, Surface and Coatings Technology 206, 2977 (2012).

59. C. Bargraser, P. Mohan, K. Lee, B. Yang, J. Suk, S. Choe and Y. Sohn, Materials Science and Engineering: A 549, 76 (2012)

60. C.-J. Li, Y. Li and G.-J. Yang, C-X and Li. Journal of Thermal Spray Technology 22, 1374 (2013). 